\title{
Pelatihan Penyusunan Instrumen Penilaian Keterampilan Menafsirkan Grafik Bagi Guru IPA Tingkat SMP di Sleman, Yogyakarta
}

\section{Training of Development of Assessment for Interpetation Skill of Graphic for Science Teachers of Junior High School (SMP) in Sleman, Yogyakarta}

\author{
Eko Widodo*, Al. Maryanto, dan Didik Setyawarno
}

*Pendidikan IPA, FMIPA, UNY, email: eko_widodo@uny.ac.id

\begin{abstract}
Abstrak
Pembelajaran IPA sangat menekankan keterampilan proses sains, salah satunya adalah keterampilan mengomunikasikan data percobaan dalam bentuk grafik dan mampu menafsirkan/interpretasi grafik tersebut. Penilaian IPA di beberapa sekolah belum dirasa optimal dalam mengembangkan keterampilan menggambar dan menafsirkan grafik. Tujuan kegiatan program pengabdian (PPM) ini adalah untuk meningkatkan pemahaman guru IPA di Sleman Yogyakarta tentang keterampilan proses sains dalam pembelajaran IPA sebagai dasar pengembangan instrumen penilaian berbasis grafik. Kegiatan pelatihan ini diperuntuk bagi guru-guru IPA di Depok, Sleman Yogyakarta. Pelaksanaan dilaksanakan Sabtu, 1 Oktober 2016 di Lab. IPA FMIPA UNY. Pelatihan ini diikuti oleh 16 peserta dari target 26 peserta dari guru-guru IPA SMA di Sleman, Yogyakarta. Kegiatan PPM dilaksanakan dengan cara tutorial (Tatap Muka), workshop, penugasan terstruktur, dan konsultasi tugas. Evaluasi kegiatan PPM dilakukan dengan angket dan penilian tugas yang dikumpulkan. Hasil kegiatan PPM ini adalah guru mampu mengembangkan desain pembelajaran IPA yang mengoptimalkan peranan laboratorium IPA dan mampu menggambar grafik dengan prosedur yang benar dan mampu mengembankan butir soal berbasis grafik.
\end{abstract}

Kata kunci: Keterampilan Proses Sains, instrumen penilaian, grafik.

\begin{abstract}
Science learning strongly emphasizes science process skills, one of which is the skill to communicate the experimental data in graphs and is able to interpret/interpretation of the graph. Assessment of science in some schools was not considered optimal in developing the skills of drawing and interpreting graphs yet. The objective of the service program (PPM) is to improve understanding of the science teachers at Sleman, Yogyakarta on science process skills in science learning as a basis for development of graphics-based assessment instrument. This training for science teachers in Depok, Sleman, Yogyakarta. Implementation held Saturday, October 1, 2016 in the Lab. of science FMIPA UNY. The training was attended by 16 participants from the target of 26 participants from high school science teachers in Sleman, Yogyakarta. This activity is carried out by way of tutorials (Face to Face), workshops, structured assignments, and consulting assignments. Evaluate the activity was conducted by questionnaire and judging duties collected. The results of these activities are teachers able to develop designs of science learning that can optimize the role of science laboratories and can draw a graph with the correct procedures and can develop items based on graphic.
\end{abstract}

Key words: science process skills, instrument of assessment, graphic.

\section{PENDAHULUAN}

Kemajuan suatu negara dapat dilihat dari bagaimana kualitas pendidikannya. Semakin tinggi kualitas pendidikan suatu bangsa, semakin maju negaranya, dan sebaliknya. Setiap jenjang pendidikan mengembangkan peserta didiknya sesuai dengan perkembangan mentalnya untuk mencapai kompetensi yang telah 
dirumuskan setiap jenjangnya, baik spiritual, sosial, pengetahuan maupun keterampilan. Prestasi belajar siswa yang masih rendah dalam mata pelajaran IPA merupakan salah satu pokok permasalahan pendidikan IPA di Indonesia. Kualitas pendidikan tersebut dikhawatirkan terus merosot akibat rendahnya mutu profesionalisme guru.

Guru merupakan faktor kunci dalam keberhasilan proses pendidikan karena guru yang menerapkan pembelajaran di kelas. Selain itu, kuantitas maupun kualitas guru sampai saat ini juga selalu menjadi perhatian pemerintah dan masyarakat. Salah satu cara dalam meningkatkan kemampuan guru adalah melalui pelatihan. Pemerintah telah bekerja sama dengan lembaga pendidikan dalam hal ini dengan perguruan tinggi telah mengadakan pelatihan-pelatihan bagi guru-guru IPA di berbagai daerah Indonesia, akan tetapi prestasi belajar IPA masih belum terjadi kenaikan secara signifikan.

Laporan United Development

Project UNDP tahun 2015 mengumumkan dalam Human Development Index (HDI), Indonesia menunduduki peringkat ke 110 di antara bebagai negara di dunia (UNDP, 2015:2). Secara umum dapat dipahami bahwa rendahnya mutu SDM bangsa Indonesia saat ini adalah akibat rendahnya mutu pendidikan. Dalam hal literasi Matematika dan Sains, hasil studi Trends in International Mathematics and Science Study (TIMSS) tahun 2007, hasilnya memperlihatkan bahwa peserta didik Indonesia belum menunjukkan prestasi memuaskan. Berdasarkan kondisi tersebut menekankan bahwa berbagai pendidikan dan pelatihan dari pemerintah melalui perguruan tinggi sangat diperlukan bagi guru-guru di sekolah untuk meningkatkan kompetensi guru sehingga kualitas pendidikan semakin baik.

Kompetensi profesional guru IPA dalam membelajarkan materi dan mengembangkan instrumen penilaian hasil belajar merupakan faktor penting dalam meningkatkan kualitas pendidikan IPA. Pembelajaran IPA di SMP dilakukan secara terpadu, sedangkan di SMA dilakukan secara terpisah. Guru IPA yang profesional akan mampu membuat batasan-batasan atau kedalaman materi IPA di tingkat SMP dan SMA serta mampu mengembangkan instrumen penilaiannya. Di berbagai sekolah menunjukan bahwa guru IPA masih belum mampu memahami secara optimal batasan-batasan atau kedalaman materi IPA tingkat SMP dan tingkat SMA. Selain itu, instrumen penilaian yang dikembangkan oleh guru-guru IPA di sekolah masih belum optimal untuk mengukur prestasi belajar secara komprehensif, sebagai contoh untuk penilaian keterampilan menafsirkan grafik.

Kemampuan guru dalam keterampilan grafik dan pemanfaatan representasi grafik dalam pembelajaran sangat berpengaruh pada performance siswa. Salah satu alasan pentingnya pemahaman representasi grafik karena mampu memberikan informasi kuantitatif yang mudah dipahami. Terlebih data yang disajikan dengan grafik menjadi lebih mudah dipahami bila dibanding data yang disajikan dalam bentuk kalimat uraian. Keterampilan menyajikan data dalam bentuk grafik serta membaca atau menginterpretasi grafik dalam bentuk kalimat verbal maupun non verbal sangat diperlukan oleh calon guru, khususnya bidang fisika. Berdasarkan uraian tersebut menunjukkan bahwa sangat dibutuhkan pelatihan penyusunan instrumen penilaian keterampilan menafsirkan grafik bagi Guru IPA tingkat SMP.

Keterampilan menafsirkan/ menginterpretasi grafik merupakan salah satu keterampilan proses sains. Abungu, Okere,dan Wachanga menyatakan pendekatan keterampilan proses sains sebagai berikut.

Science process skills teaching approach is important for teaching science subjects in schools since it contributes to the understanding of abstract concepts in science, which would remain implicit if taught 
theoretically (Abungu, Okere \& Wachanga, 2014:361).

Keterampilan proses sains adalah pendekatan pembelajaran yang memfokuskan pembelajaran pada pengembangan keterampilan siswa dalam memproseskan pengetahuan, menemukan dan mengembangkan sendiri fakta, konsep, dan nilai-nilai yang diperlukan (Suryani dkk, 2015:217). Keterampilan proses sains merupakan salah satu pendekatan yang berpusat pada peserta didik. Balanay menyatakan pendekatan berpusat pada peserta didik sebagai berikut.

The student-centred approach is based on the hypothesis that students who are given the freedom to explore areas based on their personal interests, and who are accompanied in their striving for solutions by a supportive, understanding facilitator not only achieve higher academic results but also experience an increase in personal values, such as flexibility, self-confidence and social skills (Balanay, 2013 : 25).

Keterampilan menafsirkan grafik merupakan bagian dari yang tidak terpisah dalam pembelajaran IPA. Sebagian besar konsep IPA dapat dibahasakan dengan grafik. Abungu, Okere,dan Wachanga menyatakan interpretasi sebagai berikut.

Interpretation is an example of a cognitive skill, which enables students to make sense of data obtained from a practical test. There are usually many interpretations made from data obtained from an experiment, some of which may be correct while others could be incorrect (Abungu, Okere \& Wachanga, 2014:361).

Grafik merupakan merupakan visualisasi tabel data hasil pengamatan. Grafik adalah jenis representasi yang berguna dalam merangkum data, mengolah dan menafsirkan informasi baru dari data yang kompleks. Grafik sering dianggap sebagai perangkat matematika, karena berkomunikasi melalui representasi grafik membutuhkan kompetensi matematika seperti, persepsi visual, berpikir logis, ploting data, memprediksi gerakan garis, mendeduksi hubungan antara variabel dan lain-lain (Subali, 2015:269). Peranan grafik dalam bidang sains dan teknik adalah sangat penting. Grafik dapat digunakan untuk menampilkan hasil suatu hasil penelitian maupun observasi lapangan. Dengan menampilkan dalam sebuah grafik, pembaca akan dengan mudah memahami atau masalah tertentu (Supardi, 2009:1).

\section{SOLUSI/TEKNOLOGI}

Kegiatan PPM ilaksanakan dengan cara tutorial (Tatap Muka), workshop, penugasan terstruktur, dan konsultasi sebagai berikut.

1. Tutorial dan workshop: materi 1 adalah pengoptimalan peranan lab. ipa dalam pembelajaran IPA sebagai implementasi K-13.

2. Tutorial dan workshop: materi 2 adalah pengembangan instumen penilaian berbasis grafik.

3. Tugas Terstruktur:

a. Penyusunan Desain Tugas Siswa: Pembuatan berorientasi Lab. IPA dengan memanfaatkan sumber dari perpustakaan/internet.

b. Penyusunan Desain Tugas Siswa: perencanaan dan pelaksanaan penelitian sederhana yang menggunakan prinsip metode ilmiah.

c. Pembuatan grafik secara benar dengan menggunakan data tegangan $(\mathrm{V})$ terhadap kuat arus (I).

d. Analisis grafik tegangan (V) terhadap kuat arus (I) untuk menghitung nilai resistansi (R).

e. Pengembangan butir soal berbasis grafik.

4. Konsultasi Tugas: konsultasi dilakukan via email/HP, khususnya bagi peserta pelatihan yang mengalami kesulitan dalam 
menyelesaian tugas terstruktur.

Kegiatan PPM dilaksanakan pada hari Sabtu, 1 Oktober 2016 di Lab. IPA FMIPA UNY

\section{HASIL DAN DISKUSI}

PPM yang telah dilaksanakan ini merupakan PPM berbasis pelatihan yang bersifat aplikatif bagi Guru SMP di Sleman. Sebelum PPM dilaksanakan, TIM PPM melakukan koordinasi persiapan segala sesuatu yang dibutuhkan untuk kegiatan baik sebelum maupun saat pelaksanaan. Persiapan yang dilakukan oleh Tim PPM mencakup aspek akademik, administrasi, dan non-akademik. Aspek akademik yang disiapakan meliputi: pemateri utama, makalah/materi dalam bentuk ppt, alat praktikum fisika (jangka sorong dan micrometer sekrup), dan lembar penilaian/monitoring. Persiapan administrasi mencakup lembar presensi, keperluan pertanggungjawaban keuangan, dan sertifikat untuk peserta. Persiapan nonakademik mencakup ruang, LCD, dan konsumsi. Tim PPM dalam hal ini terdiri dari dosen dan laboran Lab. IPA

Pelatihan ini diikuti oleh 16 peserta dari target 26 peserta dari guru-guru IPA SMA di Sleman, Yogyakarta. Dengan berbagai keterbatasan maka peserta dibatasi sebanyak 26 orang saja. Pembatasan terkait dengan alokasi dana yang terbatas, dan keterbatasan sarana dan prasarana yang dimiliki.

Sebelum pelatihan diakhiri, Tim PPM meminta tanggapan dari peserta pelatihan melalui angket terhadap kegiatan pelatihan yang telah dilaksanakan. Secara ringkas hasil tanggapan guru dapat ditabulasikan sebagai berikut (Tabel 1 dan Tabel 2).

Tabel 1. Tanggapan Peserta untuk Materi 1

\begin{tabular}{|c|c|c|}
\hline No & $\mathbf{P}$ & $\begin{array}{c}\text { Bobot } \\
\text { Penilaian }\end{array}$ \\
\hline 1. & $\begin{array}{l}\text { Materi yang disamp } \\
\text { mendukung kompe } \\
\text { guru IPA }\end{array}$ & $\begin{array}{l}100 \% \\
\text { Peserta } \\
\text { pelatihan }\end{array}$ \\
\hline 2. & $\begin{array}{l}\text { Materi yang disar } \\
\text { mendukung imple }\end{array}$ & \\
\hline
\end{tabular}

\begin{tabular}{|c|c|c|}
\hline & K-13 & \multirow{6}{*}{$\begin{array}{l}\text { PPM } \\
\text { dengan } \\
\text { angka } \\
\text { atau } \\
\text { yang } \\
\text { berarti } \\
\text { baik dan } \\
\text { sangat } \\
\text { baik. }\end{array}$} \\
\hline 3. & $\begin{array}{l}\text { Materi yang disampaiakan } \\
\text { mudah dipahami oleh guru } \\
\text { IPA }\end{array}$ & \\
\hline 4. & $\begin{array}{l}\text { Materi yang disampaiakan } \\
\text { dapat diterapkan secara } \\
\text { langsung di sekolah }\end{array}$ & \\
\hline 5. & $\begin{array}{lr}\text { Dosen } & \text { memberi } \\
\text { kesempatan } & \text { peseta } \\
\text { pelatihan } & \text { untuk } \\
\text { bertanya/diskusi } & \text { selama } \\
\text { kegiatan berlangsung }\end{array}$ & \\
\hline 6. & $\begin{array}{l}\text { Dosen memberi bimbingan } \\
\text { secara langsung/ tidak } \\
\text { langsung terkait dengan } \\
\text { tugas yang diberikan } \\
\text { kepada guru IPA }\end{array}$ & \\
\hline 7. & $\begin{array}{lr}\text { Tugas yang } & \text { diberikan } \\
\text { berhubungan } & \text { dengan } \\
\text { materi pelatihan } & \\
\end{array}$ & \\
\hline
\end{tabular}

Keterangan: $1=$ Sangat Kurang, $2=$ Kurang, 3 = Baik, dan $4=$ Sangat Baik.

Tabel 2. Tanggapan Peserta untuk Materi 2

\begin{tabular}{|c|c|c|}
\hline No & Pertanyaan & $\begin{array}{c}\text { Bobot } \\
\text { Penilaia } \\
\text { n } \\
\end{array}$ \\
\hline 1. & $\begin{array}{l}\text { Materi yang } \\
\text { mendukung } \\
\text { guru IPA }\end{array}$ & \multirow{6}{*}{$\begin{array}{l}100 \quad \% \\
\text { Peserta } \\
\text { pelatihan } \\
\text { memberi } \\
\text { respon } \\
\text { PPM } \\
\text { dengan } \\
\text { angka } 3 \\
\text { atau } 4 \\
\text { yang } \\
\text { berarti } \\
\text { baik dan } \\
\text { sangat } \\
\text { baik. }\end{array}$} \\
\hline 2. & $\begin{array}{l}\text { Materi yang disampaikan } \\
\text { mendukung implementasi } \\
\text { K-13 }\end{array}$ & \\
\hline 3. & $\begin{array}{l}\text { Materi yang disampaiakan } \\
\text { mudah dipahami oleh guru } \\
\text { IPA }\end{array}$ & \\
\hline 4. & $\begin{array}{l}\text { Materi yang disampaiakan } \\
\text { dapat diterapkan secara } \\
\text { langsung di sekolah }\end{array}$ & \\
\hline 5. & $\begin{array}{lr}\text { Dosen } & \text { memberi } \\
\text { kesempatan } & \text { peseta } \\
\text { pelatihan } & \text { untuk } \\
\text { bertanya/diskusi } & \text { selama } \\
\text { kegiatan berlangsung }\end{array}$ & \\
\hline 6. & $\begin{array}{l}\text { Dosen memberi bimbingan } \\
\text { secara langsung/ tidak } \\
\text { langsung terkait dengan } \\
\text { tugas yang diberikan } \\
\text { kepada guru IPA }\end{array}$ & \\
\hline
\end{tabular}




\begin{tabular}{|l|lr|l|}
\hline 7. & $\begin{array}{l}\text { Tugas yang diberikan } \\
\text { berhubungan } \\
\text { materi pelatihan }\end{array}$ & $\begin{array}{r}\text { dengan } \\
\text { derihan }\end{array}$ & \\
\hline
\end{tabular}

Keterangan: $1=$ Sangat Kurang, $2=$ Kurang, 3 = Baik, dan $4=$ Sangat Baik.

Tabel 1 dan Tabel 2 secara umum menunjukkan bahwa kegiatan pendalaman materi dan pelatihan kegiatan dinilai sangat positip. Semua guru memberi respon yang positip terhadap 7 aspek dalam tabel di atas baik untuk materi 1 maupun materi 2 . Secara umum program kegiatan ini dipandang sangat mendukung kompetensi guru IPA, mendukung implementasi K-13, materi yang disampaiakan mudah dipahami oleh guru IPA, materi yang disampaiakan dapat diterapkan secara langsung di sekolah, dosen memberi kesempatan peseta pelatihan untuk bertanya/diskusi selama kegiatan berlangsung, dosen memberi bimbingan secara langsung/ tidak langsung terkait dengan tugas yang diberikan kepada guru IPA, dan tugas yang diberikan berhubungan dengan materi pelatihan.

Dari pelatihan ini dihasilkan beberapa hal sebagai berikut:

1. Guru mampu mengembangkan desain pembelajaran IPA yang mengoptimalkan peranan laboratorium IPA.

2. Guru mampu menggambar grafik dengan prosedur yang benar dan mampu mengembankan butir soal berbasis grafik.

Selain nilai respon yang baik dan sangat baik dari peserta pelatihan terkait program pengabdian (PPM), mereka diberi kesempatan untuk memberi masukan terkait dengan kompetensi lain yang mereka butuhkan untuk di waktu yang lain yaitu: sebaiknya kegiatan rutin dilaksanakan untuk topik yang berbeda, ada pelatihan pengelolaan laboratorium IPA, pemanfaatan ICT untuk pembelajaran, dan bedah soal/ kisi-kisi soal Olimpiade Sains SMP. Dengan demikian guru SMP mampu mengembangkan potensinya dan mampu mengikuti perkembangan ICT.
Berdasarkan uraian sebelumnya dapat disimpulkan bahwa Program Pengabdian (PPM) telah terlaksana dengan hasil yang baik. Hasil penilaian melalui angket dan hasil pengumpulan tugas terstruktur dari guru-guru peserta pelatihan, dapat disimpulkan beberapa hal sebagai berikut.

1. Program Pengabdian (PPM) mendukung kompetensi guru IPA dan mendukung implementasi K-13 khususnya dalam pengembangan pembelajaran IPA untuk mengoptimalisasikan fungsi Lab. IPA dan pengembangan butir soal evaluasi pembelajaran IPA berbasis grafik.

2. Materi yang disampaiakan dalam kegiatan PPM mudah dipahami oleh guru IPA dan dapat diterapkan secara langsung di sekolah.

3. Materi yang disampaiakan dalam kegiatan PPM memberi kesempatan peserta pelatihan untuk bertanya/diskusi selama kegiatan berlangsung dan memberi bimbingan secara langsung/tidak langsung terkait dengan tugas yang diberikan kepada guru IPA.

\section{KESIMPULAN}

Hasil kegiatan PPM ini adalah guru mampu mengembangkan desain pembelajaran IPA yang mengoptimalkan peranan laboratorium IPA dan mampu menggambar grafik dengan prosedur yang benar dan mampu mengembankan butir soal berbasis grafik

\section{UCAPAN TERIMA KASIH}

Ucapan terima kasih diberikan FMIPA UNY yang telah membiayai kegiatan ini sehingga kegiatan berlangsung dengan lancar.

\section{PUSTAKA}

Abungu, Okere \& Wachanga. 2014. Journal of Educational and Social Research : The Effect of Science Process Skills Teaching Approach on Secondary School Students' Achievement in 
Chemistry in Nyando District, Kenya.

Kenya : Management Egerton

University.

Ajeng Suryani, Parsaoran Siahaan, dan Achmad Samsudin. (2015). Proseding Seminar Nasional : Pengembangan Instrumen Tes untuk Mengukur Keterampilan Proses Sains Siswa SMP pada Materi Gerak. Bandung : UPI.

Ary Donald, Jacobs, Lucy Cheser, \& Razavieh, Asghar. (1982). Introduction to Researt in Education (terjemahan).Surabaya : Usana Offset Printing.

Balanay, Catherine Anne S. 2013. Internatio nal Journal of Biology Education Vol. 3 : Assessment on Students' Science Process Skills: A Student-Centred Approach. Naawan, Filipina : Mindanao State University.

Bambang Subali, Dadi Rusdiana, Harry Firman, dan Ida Kaniawati. (2015). Proseding Seminar Nasional : Analisis Kemampuan Interpretasi Grafik Kinematika pada Mahasiswa Calon Guru Fisika. Bandung : UPI.
Chiappetta, Eugene L \& Koballa, Thomas R. (2010). Science Instruction in the Middle and Secondary Schools. New York : Allyn \& Bacon.

Iftikhar Uddin Khwaja. (2013). Curriculum Development, Assessment And Evaluation. Islamabad : Iqra University Quetta.

Human Development Report. 2015. Briefing note for countries on the 2015 Human Development Report for Indonesia. Diakses pada tanggal 3 Maret 2016 di http://hdr.undp.org/sites/all/themes/hdr _theme/country-notes/IDN.pdf.

Laksmi Dewi. (2013). Grafik. Diakses pada tanggal 2 Maret 2016 di http://file.upi.edu/direktori/fip/jur. kur ikulum_dan_tek._pendidikan/1977061 32001122-

laksmi_dewi/media_grafis/media_graf is-

hsl_mhsisswa/grafik/makalah_medgra f.pdf. 